\title{
Is the Importance of Magnesium in Chronic Kidney Disease Underappreciated?
}

\author{
Delia TIMOFTE ${ }^{1}$, Andra-Elena BALCANGIU-STROESCU ${ }^{1,2}$, Dorin DRAGOS ${ }^{3,4}$, Maria Daniela TANASESCU ${ }^{3,5}$, \\ Iuliana GHENU ${ }^{3,4}$, Ileana Adela VACAROIU ${ }^{6,7}$, Adrian TULIN ${ }^{8,9 *}$, Adina MANDITA4 ${ }^{4}$, Ovidiu STIRU ${ }^{10,11}$, \\ Doina Andrada MIHAI ${ }^{12,13}$, Anca Macovei OPRESCU ${ }^{14}$, Iulian SLAVU ${ }^{9}$, Dorin IONESCU ${ }^{3,5}$, Cornelia NITIPIR ${ }^{15}$
}

\begin{abstract}
Magnesium (Mg) is one of the most important cations in the organism, essential for regulating vascular tone, cardiac rhythm, and endothelial functions. In patients with advanced stage chronic kidney disease (CKD) Mg deficit was associated in various studies with vascular calcifications and increased cardiovascular morbidity and mortality. Patients with CKD frequently have hyperparathyroidism, parathormone (PTH) being an important risk factor for vascular calcifications. Increased serum Mg levels inhibit PTH secretion and stimulate left ventricular hypertrophy, while low serum Mg levels stimulate PTH secretion. Correcting Mg de deficiency results in reduced cardiovascular mortality in these patients.
\end{abstract}

Keywords: magnesium, hypomagnesemia, chronic kidney disease, hemodialysis, peritoneal dialysis, parathormone.

\section{Rezumat}

Magneziul (Mg) este unul dintre cei mai importanți cationi din organism, esențial pentru reglarea tonusului vascular, a ritmului cardiac și a funcțiilor endoteliale. La pacienții cu boală renală cronică în stadiu avansat (ERC), deficitul de Mg a fost asociat în diferite studii cu calcificări vasculare și creșterea morbidității și mortalității cardiovasculare. Pacienții cu boală renală cronică prezintă frecvent hiperparatiroidism, parathormonul (PTH) fiind un factor de risc important pentru calcificările vasculare. Creșterea nivelului seric de Mg inhibă secreția de PTH și stimulează hipertrofia ventriculară stângă, în timp ce nivelurile scăzute de Mg din ser stimulează secreția de PTH. Corectarea deficitului de Mg are ca rezultat reducerea mortalității cardiovasculare la acești pacienți.

Cuvinte cheie: magneziu, hipomagneziemie, boală renală cronică hemodializă, dializă peritoneală, parathormon.

\footnotetext{
'Department of Dialysis, Emergency University Hospital, Bucharest, Romania

${ }^{2}$ Discipline of Physiology, Faculty of Dental Medicine, „Carol

Davila" University of Medicine and Pharmacy, Bucharest, Romania

${ }^{3}$ Department of Medical Semiology, Discipline of Internal Medicine I and Nephrology, Faculty of Medicine, "Carol Davila"

University of Medicine and Pharmacy, Bucharest, Romania

${ }^{4}$ Department of Internal Medicine I, Emergency University

Hospital, Bucharest, Romania

${ }^{5}$ Department of Nephrology, Emergency University Hospital, Bucharest, Romania

${ }^{6}$ Department of Nephrology, "Carol Davila" University of Medicine and Pharmacy, Bucharest, Romania

${ }^{7}$ Department of Nephrology and Dialysis, "Sf. Ioan" Emergency

Clinical Hospital, Bucharest, Romania

${ }^{8}$ Department of Anatomy, Faculty of Medicine, „Carol Davila”

University of Medicine and Pharmacy, Bucharest, Romania

'Department of General Surgery, "Prof. Dr. Agrippa Ionescu"

Clinical Emergency Hospital, Bucharest, Romania

${ }^{10}$ Department of Cardiovascular Surgery, Faculty of Medicine,
}

„Carol Davila" University of Medicine and Pharmacy, Bucharest, Romania

"Department of Cardiovascular Surgery „Prof. Dr. C. C. Iliescu" Emergency Institute for Cardiovascular Diseases, Bucharest, Romania

${ }^{12}$ Department of Diabetes, Nutrition and Metabolic Disease, "Carol Davila" University of Medicine and Pharmacy, Bucharest, Romania

${ }^{13}$ IInd Department of Diabetes, „N. C. Paulescu" Institute of Diabetes, Nutrition and Metabolic Diseases, Bucharest ${ }^{14}$ Department of Gastroenterology, „Prof. Dr. Agrippa Ionescu” Clinical Emergency Hospital, Bucharest, Romania

${ }^{15}$ Department of Oncology, Faculty of Medicine, „Carol Davila"

University of Medicine and Pharmacy, Bucharest, Romania

\section{Corresponding author:}

Adrian TULIN, „Prof. Dr. Agrippa Ionescu" Clinical Emergency Hospital, Bucharest, 011356, Romania.

E-mail: adrian.tulin@umfcd.ro 


\section{INTRODUCTION}

Magnesium $(\mathrm{Mg})$ has an important role, albeit rather neglected, in most enzymatic processes in the organism 1. The variations in serum $\mathrm{Mg}$ level are relevant from both a therapeutic and a preventive perspective for disorders such as: cardiovascular diseases, preeclampsia, diabetes mellitus, osteoporosis, bronchial asthma, migraines. In osteoblasts and osteoclasts $\mathrm{Mg}$ regulates the formation apatite crystals and contribute to both bone mineralization and bone remodeling ${ }^{2}$. The kidney has an essential role in maintaining magnesium balance by reabsorption and excretion, but its ability to perform these functions gradually diminishes with declining renal function ${ }^{3}$.

Cardiovascular diseases are the main cause of mortality in patients with chronic kidney disease (CKD). A significant proportion of the patients with $\mathrm{CKD}$ on renal replacement therapy (RRT) by dialysis have vascular, including coronary, calcifications ${ }^{4}$, which are intimately linked to the pathogenesis of cardiovascular diseases, that significantly increase the morbidity and mortality of patients with CKD ${ }^{4,5}$. Low $\mathrm{Mg}$ serum level is associated with vascular calcifications and with the increased cardiovascular mortality in patients with advanced stage $\mathrm{CKD}^{6,7}$.

Blood Mg level influences parathormone (PTH) secretion, which is an independent risk factor for vascular calcifications, left ventricular hypertrophy, and mortality of patients with advanced stage $\mathrm{CKD}^{2}$.

\section{EXPERIMENTAL (MATERIALS AND METHODS):}

The present review has considered the studies in the literature addressing the correlation between magnesium homeostasis and the various disorders typical for patients with CKD. Magnesium is a relatively neglected element, whose variations have significant repercussions on cardiovascular morbidity and mortality in patients with $\mathrm{CKD}$; therefore, correcting $\mathrm{Mg}$ serum level may be of both therapeutic and preventive value.

\section{RESULTS AND DISCUSSIONS}

\section{The biological role of $\mathrm{Mg}$}

Magnesium $(\mathrm{Mg})$ is one of the most important cations in the organism, involved in many enzymatic processes, in the electrolyte balance, and in the bone metabolism ${ }^{1}$.
Mg plays a fundamental role in: energy metabolism; protein, fatty acids, and nucleic acid synthesis and in the synthesis and biding of hormonal receptors ${ }^{1} . \mathrm{Mg}$ is also involved in bone mineralization, enzymes synthesis including adenylate-cyclase, regulating transmembrane ion fluxes, muscle contraction, cardiac excitability and nervous transmission ${ }^{1}$.

In the cardiovascular system, $\mathrm{Mg}$ plays an important role in regulating cardiac rhythm, vascular tone, and blood pressure. $\mathrm{Mg}$ is able to prevent both thrombosis and atherosclerosis ${ }^{1} . \mathrm{Mg}$ supplementation may reduce mortality in patients with myocardial infarction, after myocardial reperfusion injury [8]. $\mathrm{Mg}$ deficiency was associated in various studies with vascular calcifications and with increased cardiovascular mortality in patients with end stage renal disease (ESRD) $)^{1,2}$.

$\mathrm{Mg}$ may also prevent insulin resistance and osteoporosis ${ }^{1}$.

$\mathrm{Mg}$ deficiency acts as a proinflammatory factor and dampens specific immune response $e^{9,10}$.

\section{Homeostasis $\mathrm{Mg}$}

$\mathrm{Mg}$ is distributed unevenly among the various tissues: most of the $\mathrm{Mg}$ (56\%) is in the bones, which are the main $\mathrm{Mg}$ store of the organism; approximately one third is in the intracellular space, respective $27 \%$ in the muscles and $19 \%$ in soft tissues, and only $2 \%$ in extracellular space ${ }^{11,12}$.

In humans, less than $1 \%$ of the total $\mathrm{Mg}$ in the organism is in the intravascular space, either in plasma or in the red blood cells ${ }^{13}$. Blood $\mathrm{Mg}$, which accounts for about $0,3 \%$ of the total $\mathrm{Mg}$ pool in the organism, may be in one of three forms: ionized (55-70\%), protein (especially albumin) bound (20-30\%) or anionic complexes, in combination with: phosphate, citrate, bicarbonate or sulfate $(5-15 \%)^{13}$. Ionized $\mathrm{Mg}$ and $\mathrm{Mg}$ in the anionic complexes constitute the fraction of plasma $\mathrm{Mg}$ that may be eliminated by renal excretion in the urine or by dialysis ${ }^{14,15}$.

$\mathrm{Mg}$ balance in the organism depends on dietary intake, intestinal absorption, amount of $\mathrm{Mg}$ deposited in muscles and bones, and renal excretion ${ }^{3,14,16,17,18}$.

About $30-40 \%$ of the ingested $\mathrm{Mg}$ is absorbed in the gut, mainly in the distal jejunum and ileum by passive paracellular transport ${ }^{12}$ and in the ileum and colon by active transcellular transport ${ }^{19}$. In order to maintain $\mathrm{Mg}$ balance supplementary dietary intake is necessary, the recommended daily dose in adults being $420 \mathrm{mg}$ daily in males and $320 \mathrm{mg}$ daily in females. With reduced dietary magnesium intake, intestinal absorption 
may increase to up to $80 \%{ }^{20,21}$. About $10 \%$ of the daily $\mathrm{Mg}$ intake is provided by drinking water ${ }^{22}$.

$\mathrm{Mg}$ balance is regulated mainly by the kidneys, kidney filtration and reabsorption being essential for maintaining a steady blood $\mathrm{Mg}$ level between 0,75-0,9 $\mathrm{mmol} / 1$ (i.e. $7-2.4 \mathrm{mg} / \mathrm{dl}$ ) in healthy adults. The amount of $\mathrm{Mg}$ filtered daily in the glomeruli is $2400 \mathrm{mg}$, $95 \%$ of which is reabsorbed in Henle loop (65\%) or in distal tubules (30\%). Only $100 \mathrm{mg}$ of $\mathrm{Mg}$ are excreted daily in the urine ${ }^{22}$.

Vitamin D, PTH, and estrogen hormones play an important role in $\mathrm{Mg}$ homeostasis ${ }^{20}$.

Hemolysis increases serum $\mathrm{Mg}$ concentration, as red blood cells contain a relatively high amount of $\mathrm{Mg}^{20}$.

\section{Disorders of magnesium balance}

Hypomagnesemia is defined by a $\mathrm{Mg}$ serum level < $1.5 \mathrm{mg} / \mathrm{dl}$.

Hypomagnesemia may have several causes, mainly insufficient intake (inadequate diet, rich in processed food; prolonged nasogastric tube feeding; poor intestinal absorption due to diarrhea, pancreatic failure, alcoholism, inflammatory bowel diseases) and excessive renal losses (renal tubular dysfunctions, diabetes mellitus, acute tubular necrosis, hyperfiltration, diuretics, increased post-obstructive diuresis, after renal transplantation, Bartter and Gitelman syndromes, hyperaldosteronism, hypercalciuria, diabetic ketoacidosis ${ }^{22}$.

Hypomagnesemia may be induced by several drugs (aminoglycosides, amphotericin B, cisplatin, cyclosporin, loop and thiazide diuretics, proton pump inhibitors) or may be the result of genetic disorders, namely autosomal dominant familial hypomagnesemia with hypercalciuria and nephrocalcinosis, with secondary hypocalcemia or associated with convulsions and mental retardation ${ }^{22}$.

$\mathrm{Mg}$ deficiency is difficult to pin down by measuring $\mathrm{Mg}$ serum level due to the low $\mathrm{Mg}$ serum concentration. One may resort to more elaborate investigations such as: red blood cells $\mathrm{Mg}$ assessment, ionized serum test, MRI spectroscopy, but these are uncommon in clinical practice, most laboratories measuring only total $\mathrm{Mg}$ serum level. Consequently, the diagnosis of $\mathrm{Mg}$ deficiency relies on identifying the clinical symptoms of hypomagnesemia, which occur when serum Mg level drops to $1.2 \mathrm{mg} / \mathrm{dl}$ : anxiety, panic attacks, irritability, insomnia, attention and concentration deficit, apathy, headache, migraines, bronchial asthma attacks, appetite loss, nausea, vomiting, constipation, weakness, tremor, convulsions, muscle cramps and spasms.
Hypomagnesemia is frequent in intensive care patients, being especially common in the aftermath of surgical interventions ${ }^{22}$.

Hypermagnesemia is defined by serum $\mathrm{Mg}$ level above $2.2 \mathrm{mg} / \mathrm{d} 1$.

Hypermagnesemia is a rare occurrence, especially in in-patients, being more common in patients with CKD and in elderly patients. At $\mathrm{Mg}$ serum levels above 7.3 $\mathrm{mg} / \mathrm{dl}$ deep tendon reflexes are abolished and at levels above $12 \mathrm{mg} / \mathrm{dl}$ potentially fatal cardiac arrhythmias may occur ${ }^{23}$.

Common causes of hypermagnesemia: lithium therapy, hypothyroidism, familial hypocalciuric hypercalcemia, Addison disease, milk-alkali syndrome, $\mathrm{Mg}$ containing medication (antiacids).

Hypermagnesemia decreases serum PTH level and enhances calcium solubility, resulting in decreased tissular calcifications ${ }^{23}$.

\section{Magnesium role in CKD}

The prevalence of CKD in general population varies from country to country, but generally is on an ascending trend, mainly due to the high prevalence of diabetes mellitus complicated with diabetic nephropathy and renal vascular diseases (hypertensive nephrosclerosis and ischemic nephropathy). In patients with CKD, cardiovascular morbidity and mortality are significantly increased compared to general population ${ }^{24}$.

The role of the kidney in $\mathrm{Mg}$ homeostasis, although vital in healthy individuals, diminishes with declining kidney function. In the kidney, $70-80 \%$ of plasma $\mathrm{Mg}$ is freely filtered in the glomeruli. Patients with CKD are vulnerable to a diet rich in $\mathrm{Mg}$ or to $\mathrm{Mg}$ containing medications including antiacids or diuretics ${ }^{22}$.

Alterations in mineral metabolism may occur as early as stage $3 \mathrm{CKD}$ (glomerular filtration rate GFR < $60 \mathrm{ml} / \mathrm{min} / 1.73 \mathrm{~m}^{2}$ ), the kidney being unable to properly excrete phosphate anions, resulting in hyperphosphatemia and secondary hyperparathyroidism. Furthermore, renal vitamin $\mathrm{D}$ conversion decreases, with consequent hypocalcemia and increased PTH levels, leading to the bone mineral disorders associated with $\mathrm{CKD}^{25}$. Vitamin D also influences $\mathrm{Mg}$ intestinal absorption, but $\mathrm{Mg}$ may also be absorbed by vitamin $\mathrm{D}$ independent mechanisms.

In the kidney, hypomagnesemia stimulates, while hypermagnesemia inhibits tubular $\mathrm{Mg}$ reabsorption. In the early stages of CKD (GFR $>30 \mathrm{ml} / \mathrm{min} / 1.73 \mathrm{~m}^{2}$ ), $\mathrm{Mg}$ excretion increases with decreasing GFR, thereby preventing hypermagnesemia, while a slight decrease 
in $\mathrm{Mg}$ serum level induces a rapid drop in urinary $\mathrm{Mg}$ excretion ${ }^{21}$. In stage $4 \mathrm{CKD}$, as GFR falls below 30 $\mathrm{ml} / \mathrm{min} / 1.73 \mathrm{~m}^{2}$ and with significant decline in renal function, hypermagnesemia is more common, especially in patients with ESRD, in which GFR $<10-15 \mathrm{ml} /$ $\mathrm{min} / 1.73 \mathrm{~m}^{2}$.

In various observational studies, hypomagnesemia was considered a predictive factor for CKD progression by only partially understood mechanisms, probably related to its role in endothelial dysfunction, inflammation, vascular calcifications, thrombotic processes, diabetes mellitus, and insulin resistance ${ }^{26}$.

Secondary hyperparathyroidism is an unavoidable complication of advanced stage CKD, calcium being the main activator of PTH secretion by means of $\mathrm{Ca}$-sensing receptor $(\mathrm{CaSR})$, but the $\mathrm{PTH}$ secretion is influenced also by the plasma $\mathrm{Mg}$, by incompletely deciphered mechanisms $s^{3}$. The relation between PTH and $\mathrm{Mg}$ is complex and similar to homeostasis $\mathrm{Ca}$ : high blood Mg levels suppress PTH secretion by activating $\mathrm{CaSR}$, in parathyroid glands. PTH is an important independent risk factor for vascular calcifications, left ventricular hypertrophy, and mortality in patients on $\mathrm{RRT}^{1}$ - thus, the PTH lowering effect of hypermagnesemia may explain its ability to decreases cardiovascular morbidity and mortality in these patients. By contrast, low serum $\mathrm{Mg}$ level stimulate PTH secretion.

On the other hand, PTH stimulates $\mathrm{Mg}$ reabsorption in distal tubule and increases $\mathrm{Mg}$ release from the bones $^{22}$.

In patients on RRT by dialysis, the quantity of total and ionized $\mathrm{Mg}$ in the serum is slightly increased, depending on the residual renal function, on diet, but also on the removal by dialysis. Moreover, a negative $\mathrm{Mg}$ balance may be the result of diuretic treatment in the early stages of CKD or of decreased intestinal $\mathrm{Mg}$ absorption secondary to acidosis. In patients on RRT, bone $\mathrm{Mg}$ increases to up to $66 \%$, both in the cortical and trabecular bone, indicating an increase in total $\mathrm{Mg}$ in the organism in these patients ${ }^{1}$.

\section{Magnesium and peritoneal dialysis}

In patients with CKD on RRT by peritoneal dialysis (PD), $\mathrm{Mg}$ dialysate concentration is a major determinant of $\mathrm{Mg}$ homeostasis. A magnesium concentration of $0.75 \mathrm{mmol} / 1$ in the $\mathrm{PD}$ solution results in moderate hypermagnesemia ${ }^{1}$. The intake of $\mathrm{Mg}$ containing medicines (laxatives, antacids) may also contribute to the high serum $\mathrm{Mg}$ level in these patients ${ }^{1}$.

A study performed by Navarro and colab. on $51 \mathrm{de}$ patients on PD for at least 6 months, showed that patients with low PTH serum levels had serum Mg level significantly higher than patients with high PTH serum levels, pointing out an inverse correlation between PTH and serum $\mathrm{Mg}^{27}$.

Saba and colab. reported similar results in 26 patients on $\mathrm{PD}$ in which three different $\mathrm{Mg}$ concentrations in PD solution were employed: $0.75 ; 0.5 ; 0.25 \mathrm{mmol} / \mathrm{l}$. Serum PTH level was lower in patients using solutions with higher $\mathrm{Mg}$ concentration; the authors concluded that dialysis solutions high in $\mathrm{Mg}$ may prevent secondary hyperparathyroidism and, consequently, vascular calcifications and cardiovascular death ${ }^{28}$.

\section{Mg in hemodialysis}

In patients on hemodialysis, serum $\mathrm{Mg}$ concentration is direct proportional with $\mathrm{Mg}$ content of the dialysate. Generally, $\mathrm{Mg}$ concentration in the dialysis fluid is $0.75 \mathrm{mmol} / 1$. In several studies in which a dialysate low in $\mathrm{Mg}(0.6 \mathrm{mg} / \mathrm{dl})$, patients had a $\mathrm{Mg}$ serum level between $1.7-2.5 \mathrm{mg} / \mathrm{d} 1$.

Low $\mathrm{Mg}$ concentration in the dialysate was associated with higher PTH serum level, which is recognized as an independent risk factor for vascular calcifications, left ventricular hypertrophy and mortality cardiovascular in patients on hemodialysis. $\mathrm{Mg}$ deficiency was correlated with vascular and mitral calcifications in patients on hemodialysis, frequent in these patients, associated with hyperparathyroidism, increased calcium phosphate product, duration of dialysis, and age ${ }^{1}$.

On the other hand, by the effect on the vascular smooth muscle and by intradialytic variations, hypomagnesemia was associated with intradialytic hypotension and with ventricular arrhythmias, significantly contributing to the increased cardiovascular morbidity and mortality in patients on hemodialysis ${ }^{1}$.

In a study performed on 47 patients on hemodialysis, Turgut and colab. have demonstrated an inverse correlation between $\mathrm{Mg}$ serum level and carotid intima-media thickness measured by carotid Doppler echography, proving the beneficial effect of $\mathrm{Mg}$ supplementary oral intake for 2 months on PTH serum level and on intima-media thickness ${ }^{29}$.

Valvular calcifications occur with increased frequency in dialysis patients and are associated with an increased prevalence of arrhythmias and conduction defects, with left ventricular diastolic dysfunction, and with dilatated cardiomyopathy. In about $30 \%$ of dialysis patients various arrhythmias were identified by ambulatory ECG monitoring, some of them severe, their 
prevalence increasing with age, left ventricular hypertrophy, preexistent cardiac disease, and the coexistence of electrolyte disorders that may alter cardiac conduction $(\mathrm{K}, \mathrm{Ca}, \mathrm{Mg}){ }^{25}$.

The protective ability of $\mathrm{Mg}$ against mitral calcifications in hemodialysis patients was demonstrated by Tzanakis and colab in a study on 56 patients, those with and without valvular calcifications (as detected by echocardiography) having similar serum levels of calcium, phosphates, calcium phosphate product, and PTH, and only differed by $\mathrm{Mg}$ serum level. A Mg serum level below $3 \mathrm{mg} / \mathrm{dl}$ was associated with a twofold increase in mitral annulus calcifications compared to a $\mathrm{Mg}$ serum level above $3 \mathrm{mg} / \mathrm{dl}^{1,30}$.

\section{Mg in patients with renal transplant}

Immunosuppressant medication employed after renal transplantations, especially treatment regimens including calcineurin inhibitors (cyclosporin, tacrolimus) induce hypomagnesemia by inhibiting $\mathrm{Mg}$ reabsorption in the renal tubules. Some studies ${ }^{31}$ have demonstrated that low serum $\mathrm{Mg}$ levels were associated with an increased rate of functional decline of the transplanted kidney and of graft rejection. Furthermore, oral $\mathrm{Mg}$ supplementation in patients after renal transplantation has been shown to prevent cyclosporin nephrotoxicity ${ }^{1}$.

\section{References}

1. Kanbay, M., Goldsmith, D., Uyar, M.E., Turgut, F., Covic, A., Magnesium in Chronic Kidney Disease: Challenges and Opportunities, Blood Purification, 2010, 29, 280-292. doi:10.1159/000276665.

2. Ganesh SK, Levin NW, Hulbert-Shearon T, Port FK, Association of elevated serum $\mathrm{PO}(4), \mathrm{Ca} \times \mathrm{PO}(4)$ product, and parathyroid hormone with cardiac mortality risk in chronic hemodialysis patients, J Am.Soc.Nephrol., 2001 oct.12:2123-2138

3. Cunningham J., Rodriguez M., Messa P., Magnesium in chronic kidney disease Stages 3 and 4 and in dialysis patients, Clin Kidney J (2012) 5[Suppl 1]: i39-i51.

4. Goodman WG, Goldin J, Kuizon BD, Yoon C, Gales B, Sider D, et al: Coronary-artery calcification in young adults with end-stage renal disease who are undergoing dialysis, N Engl J Med 2000; 342: 1478-1483

5. Blacher J, Guerin AP, Pannier B, Marchais SJ, London GM: Arterial calcifications, arterial stiffness, and cardiovascular risk in endstage renal disease, Hypertension 2001; 38: 938-942

\section{CONCLUSIONS}

Many studies have demonstrated a protective role of $\mathrm{Mg}$ in preventing calcifications, atherosclerosis, cardiac arrhythmias, and cardiac disease in patients with CKD. In dialysis patients, serum $\mathrm{Mg}$ level is correlated with PTH level; moderate chronic hypermagnesemia is associated with low PTH levels and effectively prevents vascular and valvular calcifications, arrhythmias, and chronic myocardial ischemia. Correcting $\mathrm{Mg}$ deficiency results in decreased cardiovascular mortality, generally increased in patients on chronic dialysis.

Compliance with ethics requirements: The authors declare no conflict of interest regarding this article. The authors declare that all the procedures and experiments of this study respect the ethical standards in the Helsinki Declaration of 1975, as revised in 2008(5), as well as the national law. Informed consent was obtained from all the patients included in the study.

6. Turgut F, Kanbay M, Metin MR, Uz E, Akcay A, Covic A. Magnesium supplementation helps to improve carotid intima media thickness in patients on hemodialysis, Int Urol Nephrol. 2008;40(4):107582. doi: 10.1007/s11255-008-9410-3. Epub 2008 Jun 21. PMID: 18568412

7. Tzanakis I., Virvidakis K., Tsomi A., Mantakas E., Girousis N., Karefyllakis $\mathrm{N}$. et al, Intra and extracellular magnesium levels and atheromatosis in haemodialysis patients, Magnes Res 2004;17:102-108.

8. Baxter GF, Sumeray MS, Walker JM: Infarct size and magnesium: insights into LIMIT-2 and ISIS-4 from experimental studies. Lancet 1996; 348: 1424-1426.

9. Malpuech-Brugere C, Nowacki W, Daveau M, Gueux E, Linard C, Rock $E$, et al: Inflammatory response following acute magnesium deficiency in the rat. Biochim Biophys Acta 2000; 1501: 91-98.

10. Malpuech-Brugere C, Nowacki W, Rock E, Gueux E, Mazur A, Rayssiguier $Y$ : Enhanced tumor necrosis factor-alpha produc- 
tion following endotoxin challenge in rats is an early event during magnesium deficiency. Biochim Biophys Acta 1999; 1453: 35-40.

11. Fawcett WJ, Haxby EJ, Male DA., Magnesium: physiology and pharmacology. Br J Anaesth. 1999 Aug;83(2):302-20. doi: 10.1093/bja/83.2.302. PMID: 10618948.

12. Elin RJ: Assessment of magnesium status for diagnosis and therapy. Magnes Res 2010; 23:S194-S198.

13. van de Wal-Visscher E.R., Kooman J.P., van der Sande F.M.: Magnesium in Chronic Kidney Disease: Should We Care? Blood Purif 2018;45:173-178. doi: 10.1159/000485212

14. de Baaij JH, Hoenderop JG, Bindels RJ: Regulation of magnesium balance: lessons learned from human genetic disease. Clin Kidney J, 2012; 5(suppl 1):i15-i24.

15. Huijgen HJ, Van Ingen HE, Kok WT, Sanders GT: Magnesium fractions in serum of healthy individuals and CAPD patients, measured by an ion-selective electrode and ultrafiltration. Clin Biochem 1996; 29: 261-266.

16. Jahnen-Dechent W, Ketteler M: Magnesium basics. Clin Kidney J 2012; 5(suppl 1):i3-i14

17. Felsenfeld AJ, Levine BS, Rodriguez M: Pathophysiology of calcium, phosphorus, and magnesium dysregulation in chronic kidney disease. Semin Dial 2015; 28: 564-577

18. Saris NE, Mervaala E, Karppanen $H$, Khawaja JA, Lewenstam A: Magnesium. An update on physiological, clinical and analytical aspects. Clin Chim Acta 2000; 294: 1-26

19. Quamme GA: Recent developments in intestinal magnesium absorption. Curr Opin Gastroenterol, 2008; 24: 230-235.

20. Arnaud MJ., Update on the assessment of magnesium status. Br J Nutr. 2008 Jun; 99 Suppl 3:S24-36. doi: 10.1017/ S000711450800682X. PMID: 18598586.

21. Schrier RW, Renal and Electrolyte Disorders, ed 8,2018,pag 447488

22. Al Alawi A.M., Majoni S.W., Falhammar H., Magnesium and Human Health: Perspectives and Research Directions, Hindawi International Journal of Endocrinology, Volume 2018, Article ID 9041694
23. Ursea N., Solutia de dializa- Rinichiul artificial si alte mijloace de epuratie extrarenala, Fundatia Romana a Rinichiului, 1997, pag 147-186

24. Timofte D., Dragoș D., Măndiță A., Balcangiu-Stroescu A.E., Tănăsescu M.D., Bălan D.G., Răducu L., Avino A., Ionescu D., Risk factors for stroke in patients with chronic kidney disease, Internal Medicine 20 vol. LXVII No. 1, pg. 35-44; www.srmi.ro 20 II;10.2478 20 100; doi.org/10.2478/INMED-2020-0100

25. Covic A., Nefrologie. Principii teoretice si practice, Casa Editoriala Demiurg, lasi, 2018, pag.601-604

26. Tin A, Grams ME, Maruthur NM, Astor BC, Couper D, Mosley TH, et al., Results from the Atherosclerosis Risk in Communities study suggest that low serum magnesium is associated with incident kidney disease, Kidney Int. 2015;87:820-7.

27. Navarro JF, Mora C, Macia M, Garcia J., Serum magnesium concentration is an independent predictor of parathyroid hormone levels in peritoneal dialysis patients, Perit Dial Int. 1999 SepOct;19(5):455-61. PMID: 11379859.

28. Saha HH, Harmoinen AP, Pasternack Al., Measurement of serum ionized magnesium in CAPD patients., Perit Dial Int. 1997 JulAug;17(4):347-52. PMID: 9284461.

29. Turgut F, Kanbay M, Metin MR, Uz E, Akcay A, Covic A., Magnesium supplementation helps to improve carotid intima media thickness in patients on hemodialysis., Int Urol Nephrol. 2008;40(4):1075-82. doi: 10.1007/s11255-008-9410-3. Epub 2008 Jun 21. PMID: 18568412.

30. Tzanakis I., Virvidakis K., Tsomi A., Mantakas E., Girousis N., Karefyllakis $\mathrm{N}$. et al, Intra and extracellular magnesium levels and atheromatosis in haemodialysis patients, Magnes Res 2004;17:102-108.

31. Holzmacher R., Kendziorski C., Michael Hofman R., Jaffery J., Becker B., Djamali A., Low serum magnesium is associated with decreased graft survival in patients with chronic cyclosporin nephrotoxicity, Nephrol Dial Transplant. 2005; 20:1456-1462. 